\title{
ANALISIS KOMPARATIF PERAN ADAT DAN KEPERCAYAAN DALAM PENINGKATAN KUALITAS LINGKUNGAN PERMUKIMAN BERKACA PADA ADAT YANG ADA DI PERMUKIMAN TRADISIONAL
}

\author{
Made Widiadnyana Wardiha ${ }^{1}$ \\ $\left.{ }^{1}\right)$ Balai Penelitian dan Pengembangan Perumahan Wilayah II Denpasar, Werdhapura Village \\ Center, Jalan Danau Tamblingan No. 49, Sanur, Denpasar, Indonesia 80228 \\ e-mail: made.wardiha@puskim.pu.go.id
}

\begin{abstract}
Abstrak
Pembangunan fasilitas air minum dan sanitasi secara swadaya merupakan salah satu cara untuk melibatkan masyarakat dalam program pembangunan. Walaupun masyarakat sudah dilibatkan, namun pemanfaatan fasilitas oleh masyarakat seringkali belum maksimal. Kurangnya kesadaran masyarakat menjadi salah satu faktor. Faktor lainnya yang kemungkinan berperan adalah karena kurang diperhatikannya aspek adat dan kepercayaan dalam proses pembangunan. Makalah ini mencoba mengkaji mengenai peran adat dan kepercayaan masyarakat dalam pembangunan fasilitas untuk meningkatkan kualitas lingkungan permukiman. Tujuannya adalah untuk memberikan salah satu aspek yang dapat diperhatikan apabila akan memberikan sosialisasi atau membangun infrastruktur sanitasi bagi masyarakat. Metode yang digunakan dalam kajian ini yaitu pengumpulan hasil-hasil penelitian yang telah dilakukan dari tahun 2010 sampai tahun 2016 mengenai adat dan kepercayaan di permukiman tradisional yang berpengaruh terhadap perilaku sanitasi masyarakat, yang kemudian dikomparasi dengan hasil penelitian ilmiah lain mengenai peran adat dan kepercayaan dalam peningkatan kualitas lingkungan di masyarakat secara umum. Hasil penarikan kesimpulan pada kajian ini adalah bahwa adat dan kepercayaan merupakan aspek yang cukup kental terkait dengan kehidupan masyarakat Indonesia, dimana hal ini perlu diperhatikan dalam upaya peningkatan kesadaran masyarakat mengenai sanitasi dan program-program pembangunan bidang air minum dan sanitasi. Pelibatan para pemimpin adat di masyarakat serta penggunaan slogan atau motto yang bernuansa adat setempat juga dapat dilakukan dalam program seperti sosialisasi kepada masyarakat.
\end{abstract}

Kata kunci: adat; kepercayaan; masyarakat; sanitasi

\begin{abstract}
Sanitation and water supply facilities development with community empowerment is one of the way to involving people into development program. Although the people have already involved, facilities usage by communities mostly not yet maximized. Lack of communities awareness becoming one factor. The other factor which possibly play role is because lack of attention to custom and beliefs aspects into development program. This paper trying to study about community's custom and beliefs role in facilities development for settlement's environmental quality improvement. The purpose is to recommend the aspect that can be considered when provide socialization or build sanitation infrastructure. The method is collecting the result of 2010 until 2016 of research about costom and beliefs at traditional settlements that affected to community sanitation behaviour, which compared with another research about general role of custom and beliefs in environmental quality improvement in the community. The conclusion is the custom and beliefs are the important aspects that have a quite thick associated to Indonesian people, where this things need to be concerned in effort of improving communities awareness and development program about water supply and sanitation. Local community leader involvement and using a motto that have local custom shades can also be conducted into the program such as socialization into the community.
\end{abstract}


Keywords: custom; belief; community; sanitation

\section{Pendahuluan}

Indonesia merupakan salah satu negara yang memiliki jumlah penduduk yang besar, hampir sekitar 238 juta manusia tinggal di Indonesia (Nasional, 2013) dan ini belum termasuk orang yang bertempat tinggal sementara seperti warga negara asing. Salah satu efek dari semakin meningkatnya penduduk adalah menurunnya kualitas lingkungan karena pembuangan limbah yang semakin meningkat dan alam dianggap sebagai objek yang bisa terus dieksploitasi sehingga pencemaran menjadi meningkat (Yunansah \& Herlambang, 2017). Salah satu cara mengatasi hal tersebut adalah dengan meningkatkan pembangunan infrastruktur seperti dalam bidang penyediaan air, drainase, jamban, tangki septik, TPS (tempat pengelolaan sampah sementara), dan lain sebagainya. Sebagian dari pembangunan tersebut bersifat bantuan dari pemerintah seperti yang dominan terjadi pada era orde baru, dan sebagian lagi merupakan swadaya masyarakat yang mulai digalakkan pasca orde baru (Asnudin, 2010). Namun, tidak sedikit dari masyarakat baik di perkotaan dan pedesaan yang tidak memanfaatkan sarana bantuan pemerintah tersebut bahkan lebih banyak lagi yang tidak membangun sendiri dan memilih untuk membuang sampah dan limbah domestik mereka ke sungai (Setyowati \& Mulasari, 2013) seperti yang terjadi di kawasan-kawasan kumuh.

Menurunnya kualitas lingkungan akibat pembuangan limbah oleh masyarakat ke lingkungan seperti sungai, bagi sebagian orang dianggap karena kurangnya kesadaran masyarakat terhadap kebersihan lingkungan. Namun, kesalahan tidak selalu ada pada masyarakatnya. Ada kemungkinan kurangnya pemanfaatan dan pemeliharaan infrastuktur sanitasi serta tidak berhasilnya program sosialisasi untuk meningkatkan kesadaran masyarakat adalah karena dalam pelaksanaannya, Pemerintah kurang memperhatikan aspek sosial budaya masyarakat seperti adat dan kepercayaan. Hal ini karena sosial budaya merupakan salah satu faktor yang berpengaruh terhadap kualitas sanitasi masyarakat (Taosu \& Azizah, 2013).

Dalam tulisan ini penulis mencoba mengkaji mengenai peran adat dan kepercayaan masyarakat yang dapat dikaitkan dengan pembangunan infrastruktur dalam rangka membentuk masyarakat yang berwawasan lingkungan. Kajian ini didasari pada beberapa hasil penelitian yang dilakukan penulis selama tahun 2010 sampai dengan 2016 di beberapa permukiman tradisional di Indonesia yang tidak sedikit mengaitkan aspek adat dan kepercayaan dalam perilaku keseharian masyarakatnya termasuk dalam aspek air minum dan sanitasi lingkungan. Tujuan dari kajian ini adalah untuk memberikan salah satu aspek yang dapat diperhatikan apabila akan memberikan sosialisasi atau akan membangun infrastruktur sanitasi bagi masyarakat.

\section{Metodologi Penelitian}

Kajian ini disusun dengan mengumpulkan hasil-hasil penelitian yang dilakukan penulis di Balai Pengembangan Teknologi Perumahan Tradisional Denpasar selama tahun 2010 sampai dengan 2016 yang terkait dengan adat, kepercayaan, dan fasilitas air minum dan sanitasi serta perilaku sanitasi masyarakat. Data-data yang dikumpulkan merupakan hasil observasi dan wawancara yang dilakukan penulis pada penelitian tersebut. Data-data tersebut dirangkum dan dilakukan komparasi dengan hasil-hasil penelitian atau kajian ilmiah yang membahas mengenai peran adat, budaya, kepercayaan dalam peningkatan kualitas lingkungan atau infrastruktur air minum dan sanitasi masyarakat. Analisis dilakukan secara deskriptif komparatif disertai penarikan kesimpulan untuk merekomendasikan aspek adat dan kepercayaan apa saja yang perlu diperhatikan dalam pelaksanaan program bidang air minum dan sanitasi.

\section{Hasil dan Pembahasan \\ Adat dan Kepercayaan dalam Keseharian Masyarakat Indonesia}

Secara harfiah, berdasarkan Kamus Besar Bahasa Indonesia, adat adalah aturan (perbuatan dan sebagainya) yang lazim diturut atau dilakukan sejak dahulu kala. Pengertian lainnya adalah wujud gagasan kebudayaan yang terdiri atas nilai-nilai budaya, norma, hukum, dan aturan yang satu dengan lainnya berkaitan menjadi suatu sistem. Di Indonesia, adat tidak hanya dilakukan oleh masyarakat tradisional, tapi hampir di seluruh daerah di Indonesia. Salah satu contohnya adalah tata cara perkawinan dan upacara kematian. Bagi masyarakat di permukiman tradisional di Indonesia, adat memiliki kaitan erat dengan keseharian masyarakatnya seperti dalam aturan 
pembuatan rumah (Widyarti \& Kurniawan, 2012), aturan organisasi masyarakat, aturan mengenai pemanfaatan hutan, pengelolaan dan pemeliharaan lingkungan (Indrawardana, 2012), dan sebagainya.

Berbeda dengan adat, kepercayaan dalam kamus besar bahasa Indonesia adalah anggapan atau keyakinan bahwa sesuatu yang dipercayai itu benar atau nyata. Dalam pengertian lainnya adalah sebutan bagi sistem religi di Indonesia yang tidak termasuk salah satu dari kelima agama yang resmi. Dalam pengertian pertama, kepercayaan bisa dianggap sebagai agama baik itu diakui secara resmi oleh negara maupun tidak karena agama terkait dengan keyakinan bahwa sesuatu yang dipercayai adalah nyata seperti Tuhan atau yang lainnya. Dalam agama, selain kepercayaan terhadap Tuhan, terdapat pula kepercayaan terhadap dosa dan hukuman terhadap dosa tersebut. Kepercayaan ini membangun tradisi atau adat istiadat yang merupakan tali pengikat kuat dalam membangun tata tertib masyarakat, dimana pelanggaran terhadap tradisi tersebut dapat menimbulkan perasaan bersalah pada diri pribadi masyarakat penganutnya (Ningrum, 2012). Kepercayaan-kepercayaan tersebut mendasari perilaku masyarakat, termasuk masyarakat Indonesia dalam kesehariannya.

Salah satu peran adat atau kepercayaan di masyarakat adalah dalam hal sanitasi atau kesehatan lingkungan. Adat dan kepercayaan ini tidak hanya dalam bentuk peraturan tertulis, tapi bisa juga dalam bentuk slogan, motto, himbauan, dan sebagainya. Sebagai contoh adalah motto "Kebersihan Adalah Sebagian dari Iman". Dengan memasukkan kata "Iman" pada motto tersebut menimbulkan harapan bagi pembuat motto agar pembaca motto tersebut jika tidak menjaga kebersihan maka dia belum cukup imannya atau belum melaksanakan perintah agamanya dengan baik. Hal ini karena kalimat tersebut bersumber dari perintah/sabda nabi dalam agama Islam (Sedayu, 2011; Masruri, 2014) atau dalam sehingga motto tersebut sangat kental bernuansakan agama atau kepercayaan masyarakat.

Selain adat dan kepercayaan, ketaatan terhadap pemuka adat atau pemuka agama juga sangat tinggi bagi masyarakat Indonesia. Salah satu contohnya seperti yang terjadi di masyarakat Bali. Kebiasaan masyarakat Bali yang melakukan persembahyangan adalah membiarkan sisa-sisa persembahyangan seperti bunga, dupa, atau plastik di tempat dia duduk (Putrawan, 2010). Sampah berupa sisa persembahyangan tersebut biasanya akan disapu oleh petugas di pura setelah persembahyangan selesai. Namun saat ini, di beberapa pura di Bali terjadi hal yang berbeda yaitu ada himbauan dari pemimpin upacara agar masyarakat setelah bersembahyang dapat memungut sampahnya dan menempatkannya di tempat sampah. Setelah dihimbau seperti itu, kesadaran masyarakat untuk membuang sampahnya di tempat sampah menjadi meningkat. Dalam hal ini, kesadaran budaya terhadap adanya lingkungan sakral / suci yang tidak boleh dikotori oleh sampah merupakan salah satu aspek yang dikedepankan untuk menggerakkan masyarakat Bali agar mengelola sampahnya (Wardi, 2011).

\section{Adat dan Kepercayaan di Permukiman Tradisional Terkait Sanitasi Lingkungan}

Pembahasan ini didasarkan pada hasilhasil penelitian di permukiman-permukiman tradisional Bali, Nusa Tenggara Barat, Nusa Tenggara Timur, dan Kalimantan pada tahun 2010 sampai dengan tahun 2016. Dari hasil penelitian-penelitian tersebut, diperoleh beberapa temuan mengenai adat dan kepercayaan yang bersifat selaras ataupun kurang selaras dengan sanitasi lingkungan. Temuan yang diperoleh ditampilkan pada Tabel 1 di bawah ini. Adat dan kepercayaan yang bersifat selaras dimaksudkan apabila adat dan kepercayaan tersebut berkontribusi positif terhadap terjaganya kualitas lingkungan. Sedangkan adat dan kepercayaan yang bersifat kurang selaras adalah sebaliknya.

Tabel 1. Adat atau kepercayaan terkait sanitasi lingkungan pada masyarakat di beberapa permukiman tradisional

\begin{tabular}{|c|c|c|}
\hline \multirow{2}{*}{ Lokasi } & \multicolumn{2}{|c|}{$\begin{array}{l}\text { Adat / Kepercayaan terkait } \\
\text { Sanitasi Lingkungan }\end{array}$} \\
\hline & Selaras & $\begin{array}{l}\text { Kurang } \\
\text { Selaras }\end{array}$ \\
\hline \multirow[t]{2}{*}{$\begin{array}{l}\text { Kampung } \\
\text { Prainatang, } \\
\text { Sumba, } \\
\text { Nusa } \\
\text { Tenggara } \\
\text { Timur }\end{array}$} & $\begin{array}{l}\text { Tidak boleh } \\
\text { membuang } \\
\text { sampah ke } \\
\text { sungai karena } \\
\text { sungai digunakan } \\
\text { untuk upacara } \\
\text { adat. } \\
\text { (Denpasar, } \\
\text { 2010) }\end{array}$ & $\begin{array}{l}\text { Tidak boleh } \\
\text { membangun } \\
\text { bangunan dari } \\
\text { beton yang } \\
\text { lebih tinggi dari } \\
1 \text { meter di } \\
\text { lingkungan } \\
\text { permukiman / } \\
\text { kampung } \\
\text { (Putri \& } \\
\text { Wardiha, 2011) }\end{array}$ \\
\hline & & $\begin{array}{l}\text { Kegiatan } \\
\text { pembersihan } \\
\text { kampung } \\
\text { dilakukan } \\
\text { setahun sekali } \\
\text { pada bulan } \\
\text { bakti yaitu } \\
\text { bulan Maret. }\end{array}$ \\
\hline
\end{tabular}




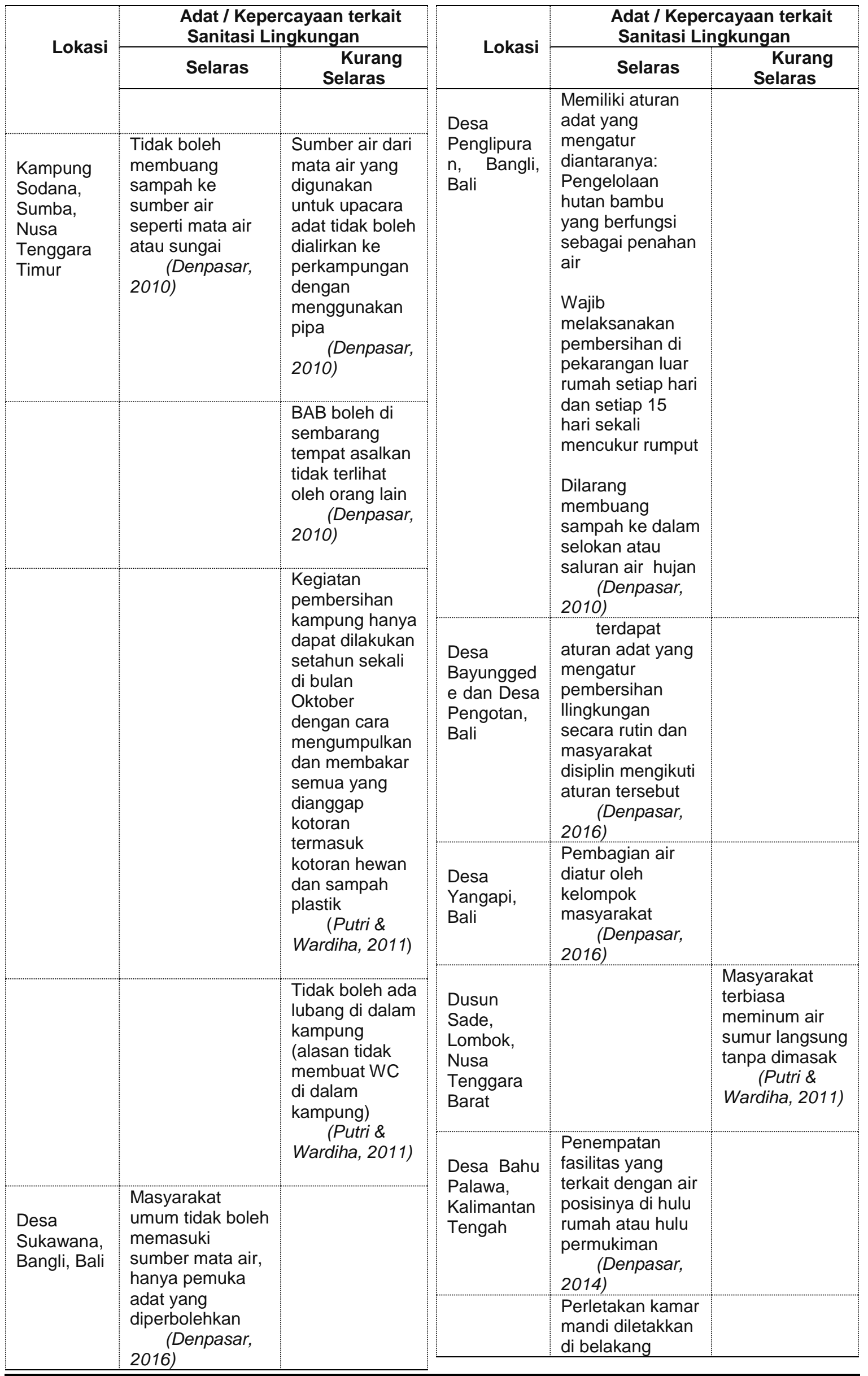




\begin{tabular}{|c|c|c|}
\hline \multirow{2}{*}{ Lokasi } & \multicolumn{2}{|c|}{$\begin{array}{l}\text { Adat / Kepercayaan terkait } \\
\text { Sanitasi Lingkungan }\end{array}$} \\
\hline & Selaras & $\begin{array}{l}\text { Kurang } \\
\text { Selaras }\end{array}$ \\
\hline & $\begin{array}{l}\text { rumah baik } \\
\text { menyatu ataupun } \\
\text { terpisah dari } \\
\text { rumah } \\
\text { (Denpasar, } \\
\text { 2014) }\end{array}$ & \\
\hline & $\begin{array}{l}\text { Hubungan } \\
\text { masyarakat yang } \\
\text { erat satu sama } \\
\text { lain } \\
\text { memungkinkan } \\
\text { pembangunan } \\
\text { fasilitas untuk } \\
\text { komunal } \\
\text { (Denpasar, } \\
\text { 2014) }\end{array}$ & \\
\hline
\end{tabular}

Berdasarkan Tabel 1 di atas terlihat bahwa adat dan kepercayaan pada masyarakat tradisional memiliki keterkaitan dengan aspek sanitasi dan kesehatan lingkungan. Kaitan yang ingin diperlihatkan pada kajian ini adalah peningkatan sanitasi dan kesehatan lingkungan masyarakat terutama masyarakat tradisional perlu memperhatikan adat dan kepercayaan. Dalam masyarakat tradisional yang kesehariannya terikat dengan adat dan kepercayaan, sangat penting untuk memasukkan unsur adat dan kepercayaan apabila akan memasukkan program pembangunan dalam bidang sanitasi.

Sebagai contoh, alasan mengapa kondisi ketersediaan fasilitas sanitasi di kampung Prainatang dan Sodana di Nusa Tenggara Timur masih kurang adalah disebabkan adanya adat yang melarang pembangunan beton atau pembuatan lubang di sekitar permukiman adat. Larangan-larangan ini perlu diperhatikan agar jangan sampai pemerintah salah memasukkan program pembangunan yang pada akhirnya ditolak oleh masyarakat. Namun, selain sebagai larangan, aturan adat di beberapa tempat juga bisa menjadi potensi seperti misalnya aturan tidak boleh membuang sampah di sungai atau aturan yang mengatur mengenai pengelolaan hutan bambu sebagai tempat untuk menahan air hujan.

Selain aturan adat, perangkat adat juga merupakan hal yang perlu diperhatikan. Dalam program pembangunan sanitasi, peran perangkat adat dapat dimanfaatkan misalnya dalam mengelola pembagian air. Pada permukiman tradisional yang masyarakatnya mengenal tata cara pembagian air oleh perangkat adat, maka para perangkat tersebut perlu dilibatkan untuk mengelola program yang akan dilaksanakan oleh pemerintah.

Penelitian yang dilakukan pada tahun 2016 di permukiman tradisional Bali memberikan hasil analisis salah satunya berupa potensi dan permasalahan yang dimiliki oleh permukiman-permukiman tersebut, yang berpengaruh terhadap penyediaan fasilitas AM PLP (Denpasar, 2016). Hasil analisis tersebut dapat dilihat pada Gambar 1 yang menggambarkan potensi dan masalah dengan menggunakan diagram fishbone. Gambar 1 tersebut memperlihatkan bahwa aspek kepatuhan terhadap adat dan peran perangkat desa merupakan potensi yang dapat dimanfaatkan peningkatan pelayanan terhadap penyediaan air minum, pengelolaan air limbah domestik, pengelolaan sampah, dan pengelolaan air hujan. Peran adat ini merupakan salah satu poin dalam menggerakkan masyarakat di Bali untuk mengelola lingkungan, seperti misalnya mengelola sampah. Seperti disebutkan dalam penelitian Wardi (2011) bahwa penyisipan masalah lingkungan khususnya pengelolaan sampah ke dalam rumusan hukum adat (awig-awig) merupakan salah satu cara meningkatkan kesadaran warga dalam mengelola sampah. Hal ini juga dilakukan oleh Pemerintah Kota Denpasar yang menganjurkan semua desa adat atau desa pakraman yang ada di Denpasar mengeluarkan "perarem" atau kesepakatan warga adat yang tertulis terkait sampah (Lestari, 2016).

Berkaca pada peran adat dan kepercayaan yang berlaku pada masyarakat tradisional, hal ini bisa diadopsi dan diterapkan kepada masyarakat yang bermukim di perkotaan atau pedesaan yang tidak termasuk permukiman tradisional. Bagi masyarakat yang tinggal di pedesaan, terutama yang berprofesi sebagai petani, penggunaan aturan adat untuk mengatur masyarakat mengelola lingkungan dapat dilakukan. Hal ini karena secara mental, masyarakat petani di Indonesia memiliki konsepsi yang lazim untuk hidup selaras dengan alam (Koentjaraningrat, 1981). Hal ini juga bisa dikaitkan dengan Gambar 1 dimana pada bagian potensi, aspek "sistem gotong royong masyarakat petani" menjadi salah satu pendukung peningkatan kualitas lingkungan. Hal ini berarti masyarakat petani di permukiman tradisional ataupun tidak, memiliki kesamaan dalam hal menganut sistem gotong royong serta sikap mental yang hidup selaras dengan alam. Selain itu masyarakat pedesaan biasanya lebih homogen (Basrowi \& Juariyah, 2010; Sadono, 2013) sehingga adat atau kepercayaan yang 
berlaku biasanya sama. Oleh karena itu, memasukkan unsur kebersihan lingkungan dalam aturan adat di pedesaan memiliki kemungkinan untuk dipatuhi. Selain itu, pembangunan bersifat swadaya yang akan diterapkan juga bisa dilakukan karena adanya potensi gotong royong pada masyarakat pedesaan. Hal ini yang bisa disebut sebagai modal sosial dalam pembangunan infrastruktur (Kusumastuti, 2015).

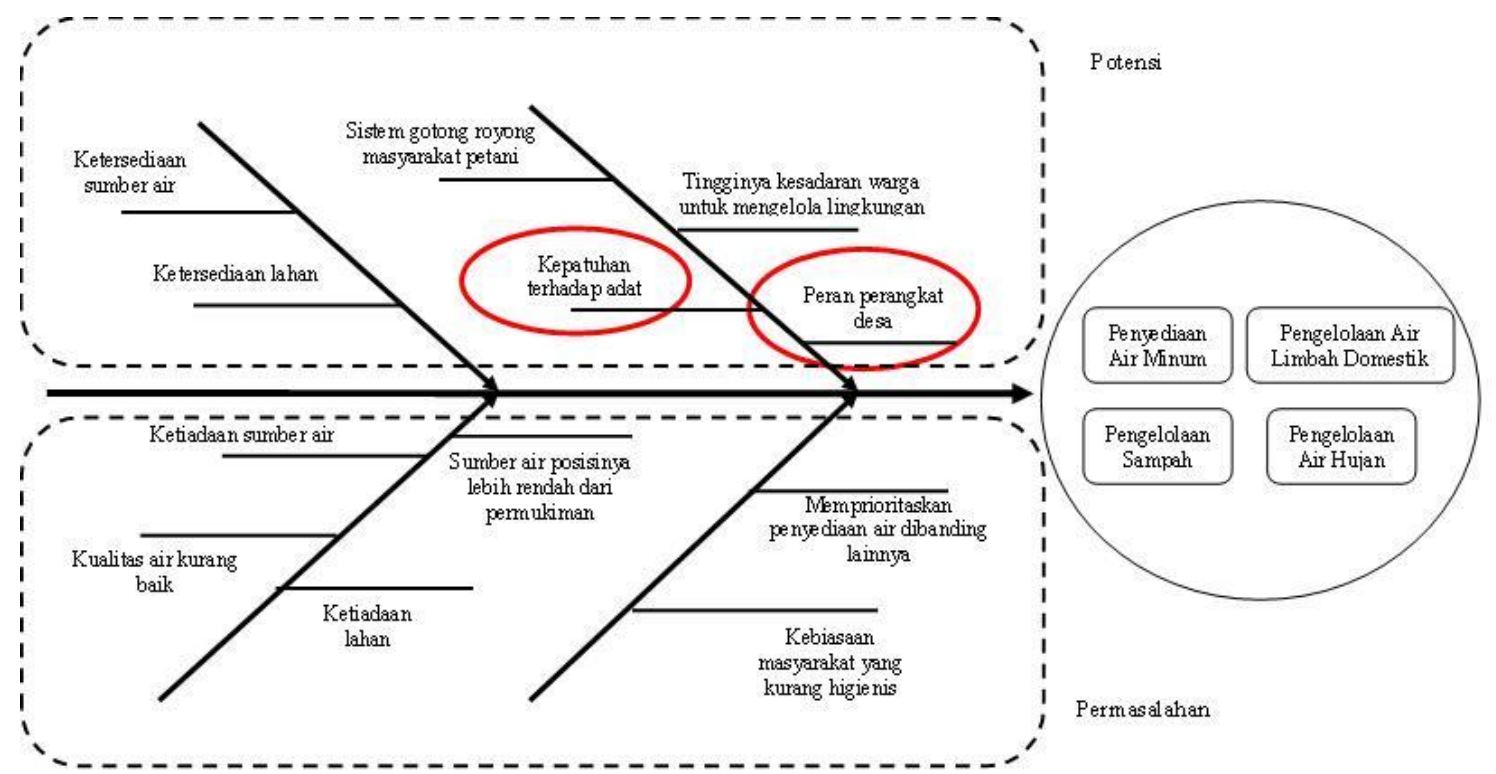

Gambar 1. Diagram Fishbone Mengenai Potensi dan Permasalahan yang Berpengaruh Terhadap Penyediaan Fasilitas AM PLP di Permukiman Tradisional Bali Sumber: (Denpasar, 2016)

Sedangkan bagi masyarakat perkotaan yang biasanya lebih plural, maka bisa memasukkan unsur kebersihan lingkungan dalam aturan yang klasifikasinya lebih umum seperti fatwa MUI (Majelis Ulama Indonesia), atau aturan organisasi agama lainnya, atau dapat pula memasukkan ke dalam kesepakatan bersama antar organisasi agama. Hal ini bisa dilakukan di kota besar seperti Jakarta. Namun, kota-kota lainnya yang masih terlihat akar budayanya seperti Jawa atau Kalimantan, tentu bisa menggunakan adat dan budaya setempat. Sebagai contoh, ketaatan masyarakat Yogyakarta terhadap Sultan merupakan salah satu aset sehingga apabila unsur kebersihan lingkungan dimasukkan ke dalam anjuran Sultan kepada masyarakat, peluang untuk dipatuhi oleh masyarakat semakin besar. Di tempat lain seperti di Kalimantan, terdapat Majelis Adat Dayak (MAD) atau Dewan Adat Dayak yang merupakan lembaga adat yang bertugas sebagai lembaga koordinasi, komunikasi, pelayanan, pengkajian dan wadah menampung dan menindaklanjuti aspirasi masyarakat (Diansyah, 2011). Masyarakat di Kalimantan yang sebagian besar merupakan masyarakat Dayak memiliki kaitan erat dengan MAD. MAD dalam fungsinya sebagai lembaga koordinasi dan komunikasi dapat dilibatkan dalam upaya pembangunan infrastruktur dan sosialisasi mengenai infrastruktur air minum dan sanitasi. Himbauan dari MAD ataupun memasukkan unsur kebersihan atau kesehatan lingkungan ke dalam aturan adat bisa dikomunikasikan melalui MAD kepada masyarakat di Kalimantan.

Berdasarkan penjelasan-penjelasan di atas, terdapat beberapa hal yang direkomendasikan apabila akan menerapkan suatu program pembangunan infrastruktur air minum dan sanitasi atau melakukan sosialisasi terkait hal tersebut yaitu diantaranya:

- Melibatkan peran perangkat adat, pemuka agama, atau pemimpin adat dalam melakukan sosialisasi. Namun, sebelum dilibatkan, perlu dilakukan diskusi dengan perangkat adat, pemuka agama, atau pemimpin adat untuk memberikan pemahaman mengenai program tersebut. Apabila program tersebut didukung oleh adat, maka bantuan perangkat adat untuk memberikan sosialisasi kepada masyarakat cukup penting untuk menggerakan masyarakat agar berperan aktif dalam program yang dicanangkan

- Merekomendasikan pemimpin daerah untuk memasukkan aspek kebersihan atau kesehatan lingkungan ke dalam 
aturan-aturan adat setempat baik dalam bentuk tertulis maupun dalam bentuk anjuran pemimpin adat terutama pemimpin adat masyarakat mayoritas di suatu wilayah

- Menggunakan istilah-istilah lokal yang bernuansa adat atau kepercayaan masyarakat setempat dalam slogan, motto ataupun himbauan mengenai kebersihan atau kesehatan lingkungan

\section{Kesimpulan}

Adat dan kepercayaan merupakan aspek yang cukup kental terkait dengan kehidupan masyarakat Indonesia di pedesaan dan perkotaan, terutama di pedesaan. Dalam upaya peningkatan kualitas lingkungan seperti pembangunan fasilitas air minum dan sanitasi serta peningkatan kesadaran masyarakat tentang kesehatan lingkungan, peran adat dan kepercayaan perlu diperhatikan. Hal-hal yang dapat dilakukan untuk memaksimalkan peran adat dan kepercayaan tersebut diantaranya dengan melibatkan peran pemimpin adat dalam pelaksanaan program peningkatan kualitas lingkungan seperti dalam sosialisasi kepada masyarakat, merekomendasikan pemimpin daerah untuk memasukkan aspek kebersihan atau kesehatan lingkungan ke dalam aturan adat setempat, serta menggunakan istilah-istilah lokal yang bernuansa adat masyarakat setempat dalam slogan, motto ataupun himbauan mengenai kebersihan atau kesehatan lingkungan

Ucapan Terima Kasih: Ucapan terima kasih disampaikan kepada Balai Penelitian dan Pengembangan Perumahan Wilayah II Denpasar dimana beberapa data yang ditampilkan pada kajian ini merupakan data hasil penelitian di balai tersebut.

\section{Daftar Pustaka}

Asnudin, A. (2010). Pendekatan Partisipatif Dalam Pembangunan Proyek Infrastruktur Perdesaan di Indonesia. Jurnal SMARTek, 8(3), 182-190.

Basrowi, \& Juariyah, S. (2010). Analisis Kondisi Sosial Ekonomi dan Tingkat Pendidikan Masyarakat Desa Srigading, Kecamatan Labuhan Maringgai, Kabupaten Lampung Timur. Jurnal Ekonomi \& Pendidikan, $7(1), 58-81$.

Denpasar, B. P. (2010). Peningkatan Kualitas Lingkungan Permukiman Tradisional melalui Penerapan Teknologi Tepat Guna. Laporan Akhir, Puslitbang
Perumahan dan Permukiman, Kementerian Pekerjaan Umum dan Perumahan Rakyat, Denpasar.

Denpasar, B. P. (2014). Kegiatan Pengkajian Teknologi Bangunan dan Lingkungan Permukiman Tradisional Suku Dayak Ngaju di Kalimantan, Sub Kegiatan: Penelitian dan Pengkajian Sarana dan Prasarana Air Minum dan PLP. Laporan Akhir, Puslitbang Perumahan dan Permukiman, Kementerian Pekerjaan Umum dan Perumahan Rakyat, Denpasar.

Denpasar, B. P. (2016). Kegiatan Pemetaan Ketersediaan dan Permasalahan Fasilitas Air Minum dan PLP di Permukiman Tradisional Provinsi Kalimantan Selatan dan Bali. Laporan Akhir, Puslitbang Perumahan dan Permukiman, Kementerian Pekerjaan Umum dan Perumahan Rakyat, Denpasar.

Diansyah, A. (2011). Eksistensi Damang Sebagai Hakim Perdamaian Adat Pada Masyarakat Suku Dayak di Palangkaraya. Tesis, Universitas Udayana, Program Studi Magister IImu Hukum.

Indrawardana, I. (2012). Kearifan Lokal Adat Masyarakat Sunda Dalam Hubungan dengan Lingkungan Alam. Jurnal Komunitas, 4(1), 1-8.

Koentjaraningrat. (1981). Pengantar IImu Antropologi. Jakarta: Penerbit Rineka Cipta.

Kusumastuti, A. (2015). Modal Sosial dan Mekanisme Adaptasi Masyarakat Pedesaan dalam Pengelolaan dan Pembangunan Infrastruktur. Masyarakat: Jurnal Sosiologi, 20(1), 81-97.

Lestari, S. (2016, April 14). Kompas.com. Dipetik Agustus 9, 2018, dari http://regional.kompas.com/read/2016 /04/14/12153231/Soal.Sampah.di.Bali .Aturan.Adat.Dinilai.Lebih.Sakti.daripa da.Perda

Masruri, U. N. (2014). Pelestarian Lingkungan dalam Perspektif Sunnah. Jurnal atTaqaddum, 6(2), 411-428.

Nasional, B. P. (2013). Proyeksi Penduduk Indonesia 2010-2035. Jakarta: Badan Pusat Statistik. 
Ningrum, E. (2012). Dinamika Masyarakat Tradisional Kampung Naga di Kabupaten Tasikmalaya. MIMBAR, XXVIII(1), 47-54.

Putrawan. (2010, April 14). Majalah Hindu Raditya. Dipetik Agustus 9, 2018, dari http://majalahhinduraditya.blogspot.co .id/2010/04/permasalahan-sampahsisa-upacara-di.html

Putri, P. S., \& Wardiha, M. W. (2011). Pendekatan Masyarakat dalam Penerapan Teknologi Tepat Guna Bidang Air Minum dan Penyehatan Lingkungan Permukiman (PLP) untuk Peningkatan Kualitas Lingkungan Permukiman Tradisional di Propinsi Bali, NTB, NTT. Proceeding Kolokium 2011 Hasil Litbang Bidang Permukiman, (hal. IV-45 - IV-59). Bandung.

Sadono, Y. (2013). Peran Serta Masyarakat dalam Pengelolaan Taman Nasional Gunung Merbabu di Desa Jeruk Kecamatan Selo, Kabupaten Boyolali. Jurnal Pembangunan Wilayah \& Kota, 9(1), 53-64.

Sedayu, A. (2011). Kamar Mandi Sebagai Tempat Bersuci (Thaharah). Jurnal Budaya Islam, 13(1), 1-21.
Setyowati, R., \& Mulasari, S. A. (2013). Pengetahuan dan Perilaku Ibu Rumah Tangga dalam Pengelolaan Sampah Plastik. Jurnal Kesehatan Masyarakat Nasional, 7(12), 562-566.

Taosu, S. A., \& Azizah, R. (2013). HUbungan Sanitasi Dasar Rumah dan Perilaku Ibu Rumah Tangga dengan Kejadian Diare Pada Balita di Desa Bena Nusa Tenggara Timur. Jurnal Kesehatan Lingkungan, 7(1), 1-6.

Wardi, I. N. (2011). Pengelolaan Sampah Berbasis Sosial Budaya: Upaya Mengatasi Masalah Lingkungan di Bali. Jurnal Bumi Lestari, 11(1), 167177.

Widyarti, M., \& Kurniawan, A. (2012). Evaluasi dan Rekonstruksi bangunan dan Sistem Sanitasi Lingkungan menurut Konsep Eco-Village di permukiman Baduy Dalam. Prosiding Seminar Nasional 1 Semesta Arsitektur Nusantara (hal. A-18 - A-25). Malang: Universitas Brawijaya Press.

Yunansah, H., \& Herlambang, Y. T. (2017). Pendidikan Berbasis Ekopedagogik dalam Menumbuhkan Kesadaran Ekologis dan Mengembangkan Karakter Siswa Sekolah Dasar. Jurnal Pendidikan Dasar, 9(1), 27-34. 